\title{
The Implementation of Character Education in Teaching English at SMP Muhammadiyah 4 Pekanbaru
}

\author{
Annisya Ulkhairi \\ State Islamic University Of Sultan Syarif Kasim Riau \\ (annisyaulkhairi94@gmail.com)
}

\begin{abstract}
Abstrak
Penelitian ini bertujuan untuk mendeskripsikan tentang implementasi pendidikan karakter dalam pengajaran bahasa Inggris dalam pembelajaran online. Karena adanya transisi antara pembelajaran tradisional ke pembelajaran online, topik ini menarik untuk diteliti. Penelitian ini dilaksanakan di SMP Muhammadiyah 4 Pekanbaru. Penelitian ini dapat dikategorikan sebagai penelitian fenomenologis yang menggunakan pendekatan kualitatif. Instrumen yang digunakan adalah lembar observasi dan pedoman wawancara. Pengumpulan data dilakukan melalui observasi, wawancara, dan dokumen. Subjek penelitian ini adalah guru bahasa Inggris SMP Muhammadiyah 4 Pekanbaru. Hasil penelitian ini menunjukkan bahwa implementasi pendidikan karakter dalam pembelajaran bahasa Inggris dalam pembelajaran online SMP Muhammadiyah 4 Pekanbaru. Diintegrasikan ke dalam tahap perencanaan, tahap belajar-mengajar, dan tahap evaluasi dengan mengembangkan nilai-nilai esensial, antara lain religius, disiplin, jujur, mandiri, tanggung jawab, kerja keras/ketekunan, rasa ingin tahu, kreativitas, kejujuran, keramahan/komunikatif, penghargaan dari prestasi. Ada beberapa faktor pendukung dan penghambat yang dihadapi dalam pelaksanaan pendidikan karakter antara lain (1) guru (2) siswa (3) orang tua yang mendukung untuk mengimplementasikan nilai-nilai dalam proses belajar mengajar dan juga beberapa tantangan seperti (1). Kurangnya pelatihan (2) tidak ada interaksi langsung (3) kurangnya motivasi dan sikap siswa (4) kurangnya dukungan orang tua dan ( kesalahan teknis). Selain itu ada beberapa cara yang dilakukan guru untuk memecahkan masalah dalam penelitian ini seperti (1) Belajar lagi dan lagi. (2) mendekati siswa (3) berkolaborasi dengan orang tua.
\end{abstract}

Keywords: Implementasi, Pendidikan Karakter, Pembelajaran Online. 


\begin{abstract}
This research was aimed to describ about the implementation of character education in teaching English in online learning. Since there is transition between tradisional learning to online learning, this topic will be interesting to be researched. This was conducted at SMP Muhammadiyah 4 Pekanbaru.This research can be categorized as phenomenological research which employs the qualitative approach. The instruments used were observation sheets and interview guides. The data were collected through observation, interview, and documents. The subjects of the research were the English teacher of SMP Muhammadiyah 4 Pekanbaru.The result of this study shows that the implementation of character education in teaching English in online learning of SMP Muhammadiyah 4 Pekanbaru. It was integrated into the planning stage, the teaching and learning stage, and the evaluation stage by developing essential virtues, including being religious, discipline, honesty, independence, responsibility, hardwork/persistence, curiosity, creativity, honesty, friendliness/ communicative, appreciation of acheivement. There are some supporting and inhibiting factors faced in implementing character education including (1) teacher (2) students (3) parents who support to implement the values in teaching and learning process and also some challenges such as (1). Lack of training (2) no direct interaction (3) lack of students' motivation and manner (4) lack of parents' support and (technical error). In addition there are some ways that teacher do to solve the problems in this research such (1) Learn again and again. (2) approach the students (3) collaborate with parents.
\end{abstract}

Keywords: implementation, character education, online learning.

\title{
Intoduction
}

Advocating character education in learning process should be a holistic movement by the education stakeholders because character is part of our generations. It is very important to be concerned as our preparation to create good generation. Character education must be given earlier since this will be have benefit for their character building and bring them to be positive attitude in 
their future (Susilawati, 2016). Students' character development is very important since teachers are the second parents at schools. As a parents teacher are expected can educate students' brain and behaviour. The US Department of Education (2005) in (Angela, p. 5) defines character education as "a learning process that enables students and adults in a school community to understand, care about and act on core ethical values such as respect, justice, civic virtue and citizenship, and responsibility for self and others. Upon such core values, we form the attitudes and actions that are the hallmark of safe, healthy and informed communities that serve as the foundation of our society". There are eighteen characters that proposed in the 2013 curriculum: spiritual; honesty; tolerance; discipline; perseverance; creativity; independence; democracy; curiosity; nationalism; patriotism; appreciation; 8friendliness or communication; love of peace; reading interest; environmental awareness; social awareness; and responsibility (Ministry of Education, 2010).

However, there is a gap between the theory and practice, in practice some English teachers are still hesitant and unsure about their understanding about character education and in integrating character education into their actual teaching practice. One of English teachers stated that there are character values in lesson plan in sylabus (theoriticaly) but in practice some teacher still have difficulties to implement it because of the lack of socialization to the teacher. Inclusion of character education in lesson plan is really needed to the teachers as their guidance for teaching but socialization to integrate it on teaching process is also important to help the teacher implement the character education without hesitant. Because of lack of socialization, it was found that the teachers were still confused in determining the implementation of character education in teaching activity. As result, some students still showed bad attitude and disrespect to the teacher, cannot be discipline and so on. It is necessary to carry out a research since the efforts of the school to enhance students' attitude through character education are still cannot show significant impact to the students. Hence, the standard for competencies achievement of the students or Minimum Criteria of Mastery Learning (KKM) in affective domain is still needed to improve. Some students got predicate $\mathrm{C}$ in their affective domain only a few of them got predicate $\mathrm{A}$.

Another problem is related to learning process. Because of covid-19 pandemic there is transition from traditional or face to face learning to online 
learning. It can be challenge to the teachers to provide good material in teaching English and also integrate character education in online learning. Ideally, teachers as role model should promoting character education directly to the students, but nowdays teachers should strugle via online learning. That should be interesting to find out how teachers implement character education in online learning activity. According to the phenomena above, the writer wants to investigate teachers' perception of implementation of character education and the implementation in classroom activity and conduct a research entitled "The Implementation of Character Education in English Teaching at SMP Muhamadiyah 4 Pekanbaru"

This research focus on exploring teacher and student's experience in implementing of character education in English learning, the research questions for this research are:

1 How is the implementation of character education in online English learning at SMP Muhamadiyah 4 Pekanbaru?

2 What are supporting factors and inhibiting factors of implementation character education through online English learning at SMP Muhamadiyah 4 Pekanbaru?

3 How does teacher solve the problems during application of character education in online English learning?

\section{Research Methods}

\section{Design}

The writer used qualitative research in the form of phenomenological research. It systematically describes the situation or object in real fact. Phenomenological research is a design of inquiry coming from philosophy and psychology in which the researcher describes the lived experiences of individuals about a phenomenon as described by participants. This description culminates in the essence of the experiences for several individuals who have all 
experienced the phenomenon (Creswell, 2014; p. 42). The phenomenon the writer wants to find out is about the character education that English teacher implements in their classroom.

\section{Site and Time}

This study conducted about from Oktober to December 2020 at SMP Muhammadiyah 4 Pekanbaru. It is located at Jl. H.R. Soebrantas, Panam, Pekanbaru.

\section{Populations and Samples}

According to Creswell (2012, p. 142), population is a group of individuals who have the same characteristics. The populations of this research are English teachers at SMP 4 Pekanbaru. There are two teachers in this school the writer chose both English teachers in SMP 4 Muhammadiyah Pekanbaru as samples of this research. The samples' data can be seen in the table below:

Table 1 A summary of samples' identity.

\begin{tabular}{cccc}
\hline Respondents & Sex & Age & Years of teaching experience \\
\hline Teacher A & Female & 26 years old & 2 years \\
\hline Teacher B & Female & 28 th years old & 2 years \\
\hline
\end{tabular}

\section{Technique of Data Collection}

To get data from the participants in research, the writer used collecting data technique. There are three main techniques of collecting data that writer used such as observation, interview, and documentation. There are two instruments for collecting the data for this research which are an observation 
sheet which are useful in obtaining the information about the description of the implementation of character education based on the situation in the classroom activities. The second instrument is an interview guide. It contains teachers' answer, ideas or opinion, so the writer can clarify the implementation while teaching. Interview guidance also can be as guidance for the writer in conducting interviews with the English teacher.

\section{Interview}

Furthermore, qualitative interviewing is usually seen as being flexible; the interviewer adjusts and responds to the interviewee, there is a great interest in the respondents point of view, detailed and rich answers are desired, the interviewer is allowed to depart from any schedule that is being utilized, new questions may arise due to respondent's replies and the order of questions may be revised (Bryman and Bell, 2007).

Thus, semi-structured interviews have been chosen as method in this thesis. In semi-structured interviews can share their own opinion freely. Before conducting interview, the writer contacted the participants to make an appointment because in this pandemic covid-19 era, the teachers worked from home and have different schedule at school. Both teachers agreed to do interview at school, but in different time, and students were interviewed after online learning. There are 3 mains questions for interview and 18 points of character values that teachers should answer. Questions of interviews were 
based on the research questions about how do teacher implementing character education in online-teaching, the supporting and inhibiting factors, also how teachers solve the problems.

\section{Documents}

Document analysis is a form of qualitative research in which documents are interpreted by the researcher to give voice and meaning around an assessment topic. In this research the writer collected public record from the teacher such as lesson plan, syllabus and teaching material. She analized these documents to find out teacher's preparation in implementing character education in planing stage of teaching. Because it is important for teachers to prepare themselve before teaching process. The writer also took audio recording, photograph, and field note as documentation.

\section{Data Analysis Technique}

According to Lodico et al. (2010:165), in all qualitative research, data analysis and interpretation are continuous throughout the study, so that insights gained in initial data analysis can guide future data collection. According to Miles and Huberman (1994:10), analysis can be define as consisting as three current flows of activity that is data reduction, data display, and conclusion drawing/verification 


\section{Findings and Discussion}

\section{How is the implementation of character education in online English learning at SMP Muhamadiyah 4 Pekanbaru?}

A Planing stage

In this study teacher already prepared lesson plan, sylabus and teaching material. In lesson plan and sylabus there is core competency (K1), both lesson plan and sylabus already have several values in K1 such as religiousity, honesty, discipline, responsibility, care (tolerance, working together), politenesss and curiosity. Also in pre-teaching, teacher showed religious values through greeting and prepare her students to praying, in discipline aspect, teacher checked students attendance list to make sure all of students joined the class on time. To enggage students' curiosity and creativity, teacher prepared a game, in this lesson plan, T1 used "words chain" also showed a picture to guess the topic. Students could give their opinion through chat roon in google meet. It is important for students to share their idea and teacher gave respond to built a good comunication between teacher and students. Students were given a chance to ask questions. To built students' discipline, T1 gave deadline for submitting the task. There was additional scor for students who can submitt the task on time as appreciation on achievement. In teaching material, T1 prepared PPT. T1 made teaching material as interesting as possible. Using picture, animation and interestung font hopely can enggage students attention and motivation in learning.

B Teaching and learning stage.

1 The implementation of character education in religiousity aspect

According to the observation result, teachers had implemented religious value in beginning and ending of the classroom activity. Teachers persuade students to pray in the beginning of classroom 
activity. By saying "pray also" "let's pray together" in classroom activities. It indicates that teachers had implemented of character in aspect of religious in beginning of classroom.

\section{The implementation of character education in honesty aspect}

Avoiding the plagiarism is one of teacher's ways to build the honesty

character. The evidence shows that teachers gave instruction to student to do the task by their own. When teacher gave task to record the dialogue, students should record their own voice and when the task is written test, students just doing with hand writing an mention their name and class. No cheating at all. To make sure the students follow the online learning process by themselve, the teacher asked them to open the camera.

In online learning it is very important for teacher to make sure students' follow the class. Do they focus and do their task by they own work, or just pretend to join the class just to fulfill the attendance list. When teacher know students doing their task without cheating it is also can help students to build their honesty.

\section{The implementation of character education in tolerance aspect}

Observation shows that teacher does not differentiate special learner's in classroom. Teacher gives opportunity for all learners to join every activity in google meet. Teacher asked who can lead the class to pray in the beginning of 
the study and also asked opinion and answer and giving a same act to accept the materials to all students without differentiate for special. It shows that tolerance had done in class. This finding is in line with indicators, which is in character nation and nation culture arranged by Kemendiknas (2010).

\section{The implementation of character education in discipline aspect}

In pre-teaching, teachers checked students' attendance in virtual classroom via google meet. The finding above shows that teacher regularly check student attendance before beginning the classroom activity. The sentence "who've joined the group?", it indicates that teachers had implemented of discipline in classroom. Checking attendance has a function to know existence of student in classroom. Teacher also implements regulation in classroom. One of regulation is coming on time in learning activity. Another indicator is teacher also gives deadline for task or homework that students should submit on time and teacher will give reward.

\section{The implementation of character education in hard work/persistence aspect}

According to observation, teachers are encouraging students to work hard to find answers to teacher questions. It can be seen from observation. When teacher asked students to find out what is the meaning of invitation. Teacher lets students to find out the answer without intervention and wait 
for the answer so it shows student to keep trying to find out the answer. In interview teacher shows her effort to make students hard work by giving video project and appreciation for the best video maker.

In the learning process, teacher create situation which could growing of mind creative. The evidence in this research confirm that character education approach used in classroom activities, which were creating of learning situation that appearing though of creative and giving of assignment which showed new creation that authentic or modification. Data from interview also confirm that how teacher showing the creative aspect in learning process, such as the material that suitable with students interest. And then encourage students to create interesting video as creative as possible such as giving reward and suggestions.

\section{The implementation of character education in independence aspect}

In learning activity, students are expected to do something without involvement of others. It means that students should rely their ability in doing something. Therefore, teachers can apply the condition of classroom which given student for independently working in classroom. In another word students have freedom to choose they choice. Observation also shows that teacher guide students to do task 
individually, as Hasan (2009) in Sri (2017) states that Attitudes and behavior are not easily dependent on others to complete tasks.

\section{The implementation of character education in democracy aspect}

The implementation this value in classroom activities through, taking decision of classroom through a discussion and also implementation learning models which are dialogic and interactive (Kementrian Pendidikan Nasional, 2010). But in online learning it is quite difficult to implement democracy values even if they use whatsaap grup. It is lack of interaction and discussion, so the teacher should be inovatif to find out another platform to make interaction more intensif.

\section{The implementation of character education in curiosity aspect}

In the process of learning, students always take an effort to know more depth about material, which is learned in classroom. It implies that teachers should help student to understand material in deeply and also making students to increase their curious in learning activity. When the teacher gave instruction for student to find out the meaning of invite and invitation, by saying "siapa yang tahu, apa itu invite dan invitation?. The students tried to find out in google the meaning and wrote in chat box. This evidence above indicates curious aspect was implemented in classroom activity. Then students tried to guessing the answer. Besides that, delivering material exploration as programmatically and the 
available media information in learning activities also strengthen this approach in classroom activity. Teacher also makes interest learning material to make students more curious to study.

\section{The implementation of character education in spirit of nations/patriotism aspect}

Patriotism is the way of thinking and showing care, and high appreciation of language, physical environment, social, cultural, economic, and political nation Hasan (2009) in Sri (2017). T1 build students' throgh unique way which is finding hero's quote. Students should know the English.

\section{The implementation of character education in nationalistic / nationalism aspect}

For this value, unfortunately the indicator of Nationalistic/ nationalism such

Pictures of the president, vice president, state symbol and Indonesian map cannot be seen in online learning. Student and teachers prefer using local brands and products.

\section{The implementation of character education in appreciation on achievement aspect}

To encourage the students, teacher needs to appreciate every achievement that the students have done. The appreciation can be a verbal or non verbal reward. Such say good job!, well done!, etc, even giving gifts, certificate or books. 


\section{The implementation of character education in friendliness/ communicative aspect}

From the datum above, we can see that there is facilitating interaction between students dialogic learning between teacher and student accepting feedback from students. Maintaining good communication to students in classroom activities, teachers are friendly in interaction with students.

\section{The implementation of character education in peace loving / tranquility aspect}

Peace loving has indicator for creating the condition of classroom remained peaceful. So, from the observation we can see that T1 asked her students to mute the speaker to make sure no noisy sound and learning process can be run well.

\section{The implementation of character education in literacy aspect}

Unfortunately there is no literacy program yet at this school. As the teacher said, literacy program is not exist, but T1 already tried to encourage students to read. as we can see in observation sheet, when T1 asked students to find out the meaning of invitation and pemission. Students search on google and read the information. 


\section{The implementation of character education in care for environment aspect}

The indicators of this value are environment is keeping the environment of classroom to clean. There is a trash bin in around the classroom Habituation of energy saving. But unfortunately, since it virtual class this value is cannot be applied.

\section{The implementation of character education in social responsibility aspect}

In traditional class the implementation of the indicators such as Empathy to

classmates with social act, building and harmony with the classmates maybe can be applied well. But since it is in online learning, it is little bit difficult to apply.

\section{The implementation of character education in responsibility aspect}

Responsibility is one of important aspects in character education, many ways for teacher to implement this value. There are some ways to teach responsibility to students in traditional learning. Such as give schedule to clean the classroom, giving schedule to be commitee an event, but since it is an online learning, teacher asks student's responsibility through giving task with deadline. Giving reward or punisment for who can or can't submitte she/he's task, it can built students' responsibility. Students who do their task by themselve also can help them to be independent and have a good problem solving skill. 


\section{Evaluation Stage}

In ealuating stage, the writer found teacher already evaluate their students based on the indicator below:

Table 2. Observation process of authentic assessment for the students' Character and their character

No Aspect and the indicators being observed

1. Responsibility

a) The students finish their task or homework given on time.

b) The students show serious attitude particularly in doing their homework and in the learning process.

2. Honesty

a) The students familiarize themselves with honesty and get themselves used to talk or tell the truth regarding to anything that they do.

b) The students admit their mistakes either when doing their assignment or anything that they do.

c) the students do their work by themselve

3. Friendlinnes/communicative aspect a The students use polite expression while coomunicate with teacher.

4. Discipline

a) The students or the learners come on time

b) The students or the learners complete the task given based on the time that has been scheduled.

c) The students or the learners obey the rules or regulations that have been approved of.

\section{The supporting factors and inhibiting factors The supporting factors}

A Internal

- Teacher

- School principals

- Students. 
B External

- Parents.

Inhibiting factors

A Internal factor

- Teacher

Accoding to observation and interview, there are sone inhibiting factor from the teacher such as

1 Lack of training.

2 No direct interactions in online learning.

- Students

1 Lack of Students' motivation

2 Lack of manner

B. External

- Parents

- Technical factor

3 The way teacher solves the problems during application of character education in online English learning

There are someways for teacher to solve the inhibiting factor:

- Learn again and again.

- Do some approaches to students

- Colaborate with parents

\section{Conclucion And Suggestions}




\section{Conclusion}

Based on the observation, interviews, and documents, it can be concluded that the implementation of character education in online-teaching to grade 8 students of SMP Muhammadiyah 4 Pekanbaru in the academic year of 20202021 is as follows.

1 SMP Muhammadiyah 4 Pekanbaru has been implementing several character education values in English teaching and learning process. In teaching English to grade students, essential virtues that are developed by the teacher being religious, discipline, honesty, independence, responsibility, hardwork/persistence, curiosity, creativity, honesty, friendliness/ communicative, appreciation of acheivement. The teacher applies the values in teaching English that show characters. The examples of classroom activities within which the character virtues emerge in the teaching and learning stage are to teach friendliness, the teacher greets the students, then the students get accustomed to greet other people cheerfully; and to teach perseverance and responsibility, the teacher encourage them by giving homework that is motivating and challenging.

2 The supporting and inhibiting factors.

Based on the finding of this research, it is considered that some supporting and inhibiting factors faced in implementing character 
education including (1) teacher (2) students (3) parents who support to implement the values in teaching and learning process and also some challenges such as (1). Lack of training (1) no direct interaction (3) lack of students' motivation and manner (4) lack of parents' support and ( technical error).

3 The way teacher solves the problems during application of character education in online English learning. There are some ways that teacher do in this research such (1) Learn again and again. (2) approach the students (3) collaborate with parents.

\section{Suggestions}

Anchored in the conclusion, some suggestions are directed to the English teacher, students, government, parents and other researchers. The suggestions are provided below.

1 To the English Teacher at SMP Muhammadiyah 4 Pekanbaru

It is necessary for the teacher to learn more about how to implement this successfully. The teacher should be more aware of the importance of English language skills and character as well. She should be more creative and resourceful in creating activities to promote character education and to promote the students' English language skills. Besides, the teacher must also establish a 
good communication with students, principle, administrators, other teachers, government, and parents, so that the relationship gets better and strengthens.

2 To the students

Students should have awarness about how important character is, having academic achievement without noble character is useless. Nothing is more important than understanding character, value, and moral are as important as knowledge.

\section{To Parents}

It is required for parents to realize the fact that their children definitely need cares and attention, so that they should support and give motivation to them. Along with the school, parents also have to promote the integration of character education in school. Furthermore, they should monitor the progress of the integration.

\section{To the Government}

According to finding, teacher said that they lack of training. So, goverment especially education ministry has homework to prepare qualify teachers who have competency in both teaching and educating and evaluate this program continuously. The government should organize workshops and seminars on character education and its implementation. 


\section{To Other Researchers}

This research is only focus on the implementing of character education in teaching English in online learning at on, . It is suggested that other researchers should study not only about the implementation, but also other aspects. Hence, it will be useful for the teachers who still have difficulties and get confused in implementing this education

\section{References}

Astalin,Prashant Kumar (2013) Qualitative Research Designs: A Conceptual Framework International Journal of Social Science \& Interdisciplinary Research, ISSN 2277- 3630 IJSSIR, Vol.2 (1), January (2013) Online available at indianresearchjournals.com

Berkowitz, and Bier, What works in Character Education: A Research-Driven Guide for Educators, (Washington:DC,2005). P.151 (Chapter 13)

Berkowitz, Marvin W. and Melinda C. Bier. 2005. What Works in Character Education: A research-driven guide for educators, http://www.rucharacter.org/file/practitioners_518.pdf.

Boyatzis, R.E., 1998. Transforming qualitative information: Thematic analysis and code development. sage.

Brown, H. Douglas. 2007. Principles of Language Learning and Teaching (Fifth Edition). California: Longman

Bryman, A. and Bell, E. (2007). Business Research Methods, 2 nd ed., Oxford: Oxford University Press.

Character Education Partnership (CEP). 2010. Eleven Principles of Effective Character Education: A Frame Work for School Sucsees. Washington DC. cited on Sunday. 23 august 2020. 
Chimezie, N (2018) Connecting Character To Conduct: Helping Students Take The Right Decisions. International Journal of Education and Research.Vol. 6 No. 2.

Creswell, J, W. (2012). Educational research: planning, conducting, and evaluating quantitative and qualitative research. Lincoln: University of Nebraska.

Glenn A. Bowen, (2009) "Document Analysis as a Qualitative Research Method", Qualitative Research Journal, Vol. 9 Issue: 2, pp.27-40, doi: 10.3316/QRJ0902027

Haryanto \& Akhirin (2018). Building Students' Character Through Integrated Teaching Learning Activities at Madrassa. Proceedings of International Conference "Internationalization of Islamic Higher Education Institutions Toward Global Competitiveness" Semarang, Indonesia - September 20th 21th, 2018 Paper No. B-58

Karim.A.A,et al,(2018). The Effectivity of Authentic Assessment Based Character Education Evaluation Model.TEM Journal. Volume 7, Issue 3, Pages 495500

Kementrian Pendidikan Nasional, Badan Penelitian dan Pengembangan Pusat Kurikulum dan Perbukuan. 2011. Panduan Pelaksanaan Pendidikan Karakter . Jakarta.

Kohn, A. (1997). How not to teach values: A critical look at character education. Phi Delta Kappan, 78(6), 428-439.

Lickona, T. 2012. Mendidik untuk Membentuk Karakter: Bagaimana Sekolah dapat Mengajarkan Sifat Hormat dan Bertanggung Jawab. Bandung: vc Bumi Aksara.

Lickona, Thomas (1992), Educating for Character: How are Schools Can Teach Respect and Responsibility. Bantam Books. USA.

Lickona, Thomas (2004), Character matters: How to help our children develop good judgment, integrity, and other essential virtues. New York: Touchstone. 
Megawangi, R. 2010. Pengembangan Program Pendidikan Karakter di Sekolah:

Pengalaman Sekolah Karakter. Jakarta: Indonesia Heritage Foundation (IHF).

Menihati Pramita Hutami (2013) "Portraying the Integration of Character Education in Teaching English as a Foreign Language to Grade XI Students of SMA Negeri 4 Yogyakarta in the Academic Year of 2011-2012: A Case Study" A Thesis English Education Department Faculty Of Languages And Arts Yogyakarta State University

Pratiwi IA (2018) The Challenges Faced By Efl Teachers In Integrating Character Education In English Subject. Lingua, Jurnal Bahasa \& Sastra, Volume 19, Nomor 1,

Robert.B \& June. S. 2006. Discovering the Real Me: Teacher's manual. Published in the United States of America by: Interreligious and International Federation for World Peace/Universal Peace Federation

Ruba Khoury (2017) Character Education as a Bridge from Elementary to Middle School: A Case Study of Effective Practices and Processes. International Journal of Teacher Leadership Khoury Character Education 49 Volume 8, Number 2, Fall 2017 ISSN: $1934-9726$

Susilawati, Rima Novia Ulfa, Hernalia Citra Dewi (2016) Integrasi Pendidikan Karakter Dalam Pembelajaran Bahasa Inggris Pada Anak Usia Dini. jumlah jurnal ilmiah kependidikan vol3 no1maret 2016, P. 6572 